This PDF is a selection from an out-of-print volume from the National Bureau of Economic Research

Volume Title: Deregulation and Interdependence in the Asia-Pacific Region, NBER-EASE Volume 8

Volume Author/Editor: Takatoshi Ito and Anne O. Krueger, editors

Volume Publisher: University of Chicago Press

Volume ISBN: 0-226-38674-0

Volume URL: http://www.nber.org/books/ito_00-1

Conference Date: June 19-21, 1997

Publication Date: January 2000

Chapter Title: Regulatory Reform and International Trade Policy

Chapter Author: Roger G. Noll

Chapter URL: http://www.nber.org/chapters/c8476

Chapter pages in book: (p. 13 - 54) 


\section{Regulatory Reform and International Trade Policy}

Roger G. Noll

An unusual feature of the contemporary debate about trade policy is its focus on regulation. In the United States, regulatory policy has been politically controversial since its inception, but until the late 1970s the debate focused on either the legitimacy of government control over various aspects of private production and transactions or whether specific areas of regulation generated positive social benefits. In Europe and Japan, the parallel policy debate during most of the twentieth century was about the boundary between public and private enterprise. In most of the world, the most common political response to a perceived performance shortfall in an important industry was to nationalize it rather than to regulate it.

In the $1980 \mathrm{~s}$, the terms of this debate shifted to more pragmatic issues. One issue area focused on rather technocratic matters: how to develop effective policies to promote competition where possible, and how to eliminate the perverse incentives of government control where competition was not possible. The other issue area was the relationship between domestic regulation and the commitment to open economies.

As the advanced industrialized nations eased into the current regime of relatively free trade, the regulatory policy debate was internationalized in three important ways. First, opponents of regulation-especially companies opposed to environmental, health, and safety regulation-argued that regulatory policy eroded the "competitiveness" of industry and con-

Roger G. Noll is the Morris M. Doyle Professor of Public Policy, Department of Economics, Stanford University, and nonresident senior fellow at the Brookings Institution.

The author gratefully acknowledges useful comments from Scott Jacobs, Akira Kawamoto, Anne Krueger, Pietro Nivola, and Bernard Phillips, and financial support for much of the work of preparing this essay from the Markle Foundation and the Organization for Economic Cooperation and Development. 
tributed to persistent trade deficits. Second, firms that were adversely affected by regulation and regulators themselves began to seek new ideas about how to reduce the financial and bureaucratic burdens of regulatory policy, a search that of ten led them to examine how these policies were carried out in other countries. Third, as direct trade barriers fell, and in many cases became negligible, countries began to incorporate regulatory policy into trade negotiations as a means of reducing indirect trade barriers.

In recent years, the regulatory reform debate has spilled over into many transitional and developing countries. Literally hundreds of state-owned enterprises have been privatized since the late 1980s, and in many cases privatization either was conducted in a manner that left the formally nationalized industry reasonably competitive or, at minimum, has opened the door to the possibility of competitive entry against incumbent monopolists.

This essay provides an overview of the international ramifications of the regulatory reform debate and the experiences of several countries with regulatory reform proposals. The essay also examines how international trade negotiations can play an important role in regulatory reform.

\subsection{The Evolution of Regulatory Reform}

In most advanced industrialized democracies, regulatory reform has been a salient political issue for two decades or more. The concept of regulatory reform is broad and somewhat vague and on occasion has been claimed by ideological proponents of either harsh or lax changes that, in reality, would be wildly inefficient. Notwithstanding these proposals, the core idea of regulatory reform--at least among scholars of business policy-is to improve the efficiency of policies that intervene in decisions about market entry, production methods, product attributes, and transactions between suppliers and customers. Reform can mean deregulation, privatization combined with the creation of a regulatory authority, or more targeted and focused regulatory reform that makes greater use of economic incentives, economic policy analysis, and policy coordination among agencies.

The debate about regulatory reform is neither empty nor sterile. Most nations have significantly changed some major regulatory policies and are considering further changes. Regulatory reform is politically salient for two main reasons. First, regulatory policies impose significant costs, and reform can reduce these costs without sacrificing regulatory objectives. Probably most of the regulatory reforms in the United States and other advanced industrialized countries that took place before 1990 were motivated primarily by the objective of improving the domestic economy by increasing the efficiency of regulated industries. Second, as direct trade barriers-tariffs and quotas on imports - have fallen, regulation has be- 
come an increasingly important source of distortions in international trade and a more frequent cause of trade conflicts. As a result, in the $1990 \mathrm{~s}$ regulatory reform increasingly was instigated as part of a broader package of reforms that were motivated by international economic policies. For example, domestic entry prohibitions in classic infrastructural industries, such as transportation, electricity, and telecommunications, as well as domestic design requirements to protect consumer health and safety, came into conflict with trade agreements that promised openness to foreign trade and investment and "national treatment" of foreign firms. Consequently, a nation's seemingly domestic regulatory policies became the subject of international controversy.

As a result of the growing importance of the international ramifications of domestic regulation, with rising frequency regulatory policy has become an issue in international negotiations about trade and investment policies. International agreements have initiated multilateral coordination of regulatory reform. For example, the vast majority of members of the World Trade Organization (WTO) have signed the voluntary agreement to liberalize telecommunications policy, and most agreed to begin implementation before the year 2000. The European Union has adopted several reforms, some incorporated into the Treaty of Rome, to harmonize environmental, health, and safety regulations and has implemented plans to liberalize airline and telecommunications regulation. Major trade liberalization agreements typically establish dispute resolution institutions to adjudicate claims that a trading partner is attempting to gain an unfair trade advantage by using regulation as an indirect trade barrier or by applying lax regulation to businesses that produce exported products. Examples are the role of the European Court of Justice in adjudicating trade disputes arising from regulation among EU countries and of the WTO in resolving similar disputes among signatories to the GATT and successor agreements.

The elevation of regulatory policy to an issue of international economic policy is controversial. Some charge that internationalizing regulatory reform is an attempt by zealots to impose stringent regulation on nations that neither need nor want it, and to turn advocates of regulatory policies into opponents of free trade. Others contend that emphasizing the trade consequences of regulation amounts to advocacy of a regulatory "race to the bottom," whereby the nations that have done the most to pursue socially desirable regulatory policies are being forced to abandon them because regulations affect trade.

The primary objective of this essay is to examine the relationship between regulatory reform and international economic integration. This essay has two main messages. First, internationalization of regulatory reform is inevitable, and not just because the social and economic problems that give rise to regulation cross borders, as is emphasized by advocates of international environmental regulation (see, e.g., Shabecoff 1996). Even 
without these cross-border problems, regulation inevitably is an international issue because, when other forms of trade barriers are low, regulations can be the main source of trade distortion. Second, internationalizing regulatory reform is not likely to produce either disaster scenario: widespread overregulation or massive underregulation. Instead, internationalization of regulatory reform is a healthy development that is likely to improve the efficiency of regulation while removing trade distortions that arise from inefficient regulation.

\subsection{Regulatory Policy and Market Access}

The guiding principle of free trade is that national boundaries should play no role in defining the potential market for any product. Distance or differences in tastes between countries might cause a firm in one country to regard sales in another country as infeasible, but not because crossing the border creates substantial impediments to the transaction. One important feature of technological progress is that it has substantially reduced the economic costs of international transactions. An especially good example is the effect of the Internet on the ease of consumer purchases. ${ }^{1}$ This example is especially relevant for thinking about the future of international cooperation in regulation because the extraordinarily rapid growth of electronic communications could massively restructure transactions arrangements.

The creation of the Internet has rapidly led to a circumstance in which anyone who owns a personal computer with a modem that connects to the telephone network can access millions of web sites all over the world that sell almost all consumer and office products. In many cases prices on web sites are substantially lower than ordinary retail prices, even if shipping charges are added, because web suppliers can avoid most distribution costs and can more easily engage in "just in time," "make to order," and other practices that reduce inventory costs. Especially in the United States, Internet transactions are growing very rapidly and conceivably could lead to a substantial reduction in retail stores within a few years.

For Internet retailing to work efficiently requires an array of domestic regulatory policies that do not create barriers to electronic commerce. Internet shopping requires that the user remain connected to a web site for a substantial period of time over the telecommunications network. In nations where connections are unreliable and frequently interrupted by poor service, Internet shopping is very difficult if not impossible. But even if the network has high quality, regulators can make Internet shopping unattrac-

1. For a more detailed discussion of trade barriers arising in Internet transactions, see Noll (1997). 
tive simply by imposing excessive usage charges for telephone service or high prices on operators of web sites. ${ }^{2}$

Likewise, Internet shopping requires that the transportation system not be so expensive that it makes transactions financially unattractive if the buyer and seller are physically separated. If transportation is regulated in a way that imposes very high prices on small-package service or discourages fast, reliable service (such as by prohibiting such service in order to protect parcel post), most Internet shopping becomes infeasible.

In similar fashion, efficient Internet transactions typically involve the use of the banking system, as customers use credit accounts or electronic funds transfer to pay for their goods. Hence, a necessary component of Internet transactions is a supportive system of regulation of commercial transactions. And, of course, the system of taxing transactions cannot impose substantially more costs on electronic transactions than on transactions through retail stores.

Finally, environmental, health, and safety regulations determine whether a buyer legally can acquire a product. Even if the product complies with all regulations at the points of manufacture and use, a system that requires elaborate testing and documentation by the buyer if the good arrives in a shipment, as contrasted to being purchased at a retail shop, also can impose a formidable barrier to Internet transactions.

The significance of these examples is that each is far more likely to present a serious problem if a transaction is arranged across a national boundary.

Usage charges for international calling are often extremely high compared to both domestic rates and the cost of service. Indeed, many countries set very high prices for origination and termination of international calls for the purpose of generating what amounts to a large tax on foreigners to subsidize domestic telephone service or in some cases to generate general government revenues. In similar fashion, international shipping rates are often several times the price for domestic shipping over comparable distances, and many countries have prohibited entry by fast package delivery services. For example, a seven-pound parcel can be shipped by two-day delivery for $\$ 15$ from New York to Los Angeles, $\$ 66$ from New York to Paris, $\$ 94$ from Paris to New York, or $\$ 61$ over the much shorter distance from Paris to Frankfurt (all prices in U.S. dollars; OECD 1995c, 12). Likewise, in some nations financial regulations, import restrictions, tariffs and the mechanism for collecting them, and currency controls impose direct costs as well as significant bureaucratic burdens on buyers who wish to make international purchases.

2. OECD (1996b, 32). Internet access prices tend to be much lower in countries that permit competition in long-distance access and information services, such as the United States. 
Finally, environmental, health, and safety regulation sometimes treats imported goods differently than domestic ones. Even when both sending and receiving countries have equivalent standards, they may not have a mutual recognition agreement, so that the same product may have to pass exactly the same test separately in every country in which it is sold (OECD 1996a). Or the product may be subject to disposal regulations that require involvement of the manufacturer or seller, so that foreign products are effectively banned, even though other disposal arrangements are easy to arrange. Environmental, health, and safety standards are a common, continuing source of trade barriers that lead to conflicts among trading partners.

The Internet shopping problem focuses on transactions in which consumers deal directly with sellers in other countries, but the revolution in electronic communications is hardly limited to this case. International specialization in production frequently causes each stage in a vertical production chain to be carried out in a different nation. Inexpensive, high-quality communications enables greater coordination and lower transactions costs at each interface in the vertical production chain. To the extent that regulatory rules interfere with these transactions, they create a potential distortion in international trade. Moreover, the importance of regulatory distortions grows as real international transactions costs decline.

Many fascinating historical disputes illustrate how, in particular, environmental, health, and safety regulation has been used to create trade barriers. Cassis de Dijon and German Bottles in the European Economic Communities (EEC) involved domestic regulations, the first about mandatory alcoholic content for liqueurs and the second about bottle recycling, that had the effect of discriminating against imports. Canadian Red Raspberries refers to a dispute under the old Canada-U.S. Free Trade Agreement, now incorporated into the North American Free Trade Agreement, in which Canadian raspberries could not be imported in the United States because, according to U.S. food regulation, they were not red enough. CAFE Standards involved a U.S. regulation that discriminated against foreign automobile manufacturers in implementing fuel efficiency regulations. Venezuelan Gasoline, the first case decided by the WTO, dealt with a U.S. statute on clean-burning gasoline that required greater improvements in imported gasoline than were demanded of domestic refiners. ${ }^{3}$ The cases involving automobile fuel efficiency and reformulated gasoline are especially instructive because in both of these cases the U.S. government quite explicitly tried to rig regulatory rules to protect domestic producers from foreign competition (Vogel 1997).

An important feature of regulatory trade distortions is that bilateral and regional trade agreements can increase, rather than reduce, these trade distortions. The textbook explanation of how bilateral agreements can

3. In each of these cases, the regulation was found to be an unfair indirect trade barrier. 
Table 1.1

Unit Production Costs and Trade Outcomes under Alternative Regulatory and Trade Regimes

\begin{tabular}{|c|c|c|c|}
\hline \multirow[b]{2}{*}{ Cost Element } & \multicolumn{3}{|c|}{ Country } \\
\hline & $\mathrm{A}$ & B & $\mathrm{C}$ \\
\hline $\begin{array}{l}\text { 1. Direct production } \\
\text { 2. Efficient }\end{array}$ & 100 & 100 & 100 \\
\hline compliance & 10 & 15 & 20 \\
\hline 3. Unit production & $\begin{array}{c}110 \\
\text { (Produce, Export) }\end{array}$ & $\begin{array}{c}115 \\
\text { (Import) }\end{array}$ & $\begin{array}{c}120 \\
\text { (Import) }\end{array}$ \\
\hline $\begin{array}{l}\text { 4. Efficient } \\
\text { externality }\end{array}$ & 13 & 5 & 15 \\
\hline 5. Unit social cost & $\begin{array}{c}123 \\
\text { (Import) }\end{array}$ & $\begin{array}{c}120 \\
\text { (Produce, Export) }\end{array}$ & $\begin{array}{c}135 \\
\text { (Import) }\end{array}$ \\
\hline $\begin{array}{l}\text { 6. Actual } \\
\text { compliance }\end{array}$ & 25 & 22 & 14 \\
\hline $\begin{array}{l}\text { 7. Actual unit } \\
\text { production }\end{array}$ & $\begin{array}{c}125 \\
\text { (Import) }\end{array}$ & $\begin{array}{c}122 \\
\text { (Import) }\end{array}$ & $\begin{array}{c}114 \\
\text { (Produce, Export) }\end{array}$ \\
\hline 8. Actual externality & 15 & 20 & 26 \\
\hline $\begin{array}{l}\text { 9. Actual unit social } \\
\text { cost }\end{array}$ & $\begin{array}{c}140 \\
\text { (Produce, Export) }\end{array}$ & $\begin{array}{c}142 \\
\text { (Import) }\end{array}$ & $\begin{array}{c}150 \\
\text { (Import) }\end{array}$ \\
\hline $\begin{array}{l}\text { 10. Tariff }=25 \\
\text { 11. Competitive price } \\
\text { elsewhere }\end{array}$ & $\begin{array}{c}25 \\
150 \\
\text { (Produce) }\end{array}$ & $\begin{array}{c}25 \\
147 \\
\text { (Produce) }\end{array}$ & $\begin{array}{c}25 \\
139 \\
\text { (Produce) }\end{array}$ \\
\hline $\begin{array}{l}\text { 12. B-C customs } \\
\text { union with } \\
\text { tariff }=10\end{array}$ & 25 & $25,10^{\mathrm{a}}$ & $25,10^{\mathrm{b}}$ \\
\hline $\begin{array}{l}\text { 13. Competitive price } \\
\text { elsewhere }\end{array}$ & $\begin{array}{c}150 \\
\text { (Produce) }\end{array}$ & $\begin{array}{l}147,132^{c} \\
\text { (Import) }\end{array}$ & $\begin{array}{c}139,124^{\mathrm{d}} \\
\text { (Produce, Export) }\end{array}$ \\
\hline
\end{tabular}

Note: Entries are explained in the text.

aTariffs against $\mathrm{A}$ and $\mathrm{C}$, respectively.

${ }^{\mathrm{b}}$ Tariffs against $A$ and $B$, respectively.

'Price plus tariff of B's output in A and C, respectively.

${ }^{d}$ Price plus tariff of C's output in A and B, respectively.

lower economic welfare is easily extended to the case of regulatory distortions. Table 1.1 constructs an example of three countries, A, B, and C, and the actual and efficient private and social costs of a product that causes an external cost through polluting emissions in its production. The example assumes that transportation costs are zero, and that the importance of this product in the economies of the three countries is low enough that conditions in this industry have no significant effect on overall trade balances and exchange rates. At equilibrium exchange rates, the example assumes that the countries have the same direct unit production costs for a particular good, shown on line 1; however, the countries have different external costs of production and different optimal and actual regulatory 
regimes. Note that in the example if no country regulates production, there will be no trade because direct private production costs will be the same everywhere.

An efficient regulatory regime would pick a regulatory rule, $R$, that would maximize social welfare:

$$
\max _{R} B(x)-C(x, R)-E(x, R),
$$

where $x$ is the rate of output and consumption, $R$ is the set of regulatory rules, $B(\cdot)$ is the benefit of $x$ to consumers and producers, $C(\cdot, \cdot)$ is production cost if in compliance with regulation, and $E(\cdot, \cdot)$ is the external harm created by production and consumption. Line 2 in table 1.1 is the incremental cost of production arising from compliance with the regulatory rule that solves the maximization problem. Line 3 is the total unit private cost of production under this rule, which is also the competitive equilibrium price if each country adopts an emission standard that is optimal in the sense that it equates marginal abatement cost to marginal damage from pollution. As shown on line 3, if every country regulates optimally, country $A$ will be the low-cost producer and so will produce for all three countries.

The example assumes that the social cost of the externality is different in each country. Line 4 shows the unit external cost in each country if that country produces according to its optimal regulatory rule. This cost varies among the countries, perhaps due to differences in the countries' natural environments or perhaps because their citizens place different values on aesthetic aspects of emissions. Line 5 is the total social cost, $C+E$, in each country, including the external cost. If producers must bear the external cost, such as would be the case if polluters were charged an emission tax, line 5 would be the competitive market price for the product in each country. Because of the particular assumptions in the table, the international specialization that would occur at these market prices is that country $\mathrm{B}$ becomes the producer for all three nations, which is not the same as on line 3. If regulatory compliance is unusually expensive in one country, the optimal regulatory regime could produce relatively small compliance expenditure and relatively large external cost, in which case, as shown, the low-cost producer on line 3 can be a high-cost producer on line 5. Likewise, all countries may face roughly the same compliance cost, but one country may attribute a very low cost to the externality, so that it has a low social cost (although not necessarily a low production cost).

Of course, optimality in the international allocation of production requires that line 5 be the basis for international specialization. This reality causes what might be called the "Lawrence Summers problem." ${ }^{4}$ Despite

4. While at the World Bank, Lawrence Summers took considerable political flack for making the observation that polluting industries should locate where their emissions cause the 
its controversial politics, optimal international specialization would allocate production of goods that creates a local external cost to countries that place a low value on that cost. In this case, producers in country $A$ have the lowest production cost; however, because country B places a low value on the remaining external cost, it has the lowest social cost and so is the most efficient producer. Of course, these results could be reversed with a small change in external cost in these countries.

Lines 6 and 8 depict an actual regulatory regime, as opposed to the theoretical ideal, showing the actual cost of compliance and external effects. Lines 7 and 9 show the international specialization that would occur at market prices that reflect only production cost and total social cost, respectively. Notice that, in this example, if external cost is not taken into account, country $\mathrm{C}$ produces the commodity, even though it has the highest social cost of production. If social cost is taken into account, then country A is the lowest cost producer.

The significance of these examples, of course, is that they demonstrate the dependence of the allocation of trade on regulatory policy in a world of putatively free trade. Lines 3, 5, 7, and 9 illustrate four possible regulatory regimes that determine the international allocation of production among the three countries. Producers in country $\mathrm{C}$ can survive only in the case depicted on lines 6 and 7: very lax domestic regulation that does not hold the industry responsible for its external cost. Implicit in the example is the assumption that from the perspective of producers in country $\mathrm{C}$, demand is highly elastic, so that the imposition of a significant regulatory cost (in this case, social-welfare-maximizing regulation) would cause the domestic industry to shut down.

Finally, lines 10 through 13 show the effects of tariffs. Lines 10 and 11 show the effect of a unit tariff of 25 . If each country imposes a tariff of 25 , no country engages in trade because its domestic production cost on line 7 is lower than the import price from other countries on line 11. The same outcome would prevail if market prices in every country reflect total social cost, for the comparison would be between line 9 and the amount on line 11 plus the external cost in that country. Note that producers in countries A and B, not to mention environmental advocates, can be expected to express a great deal of quite justified indignation about a proposal to move from the high-tariff regime on line 11 to the free trade regime on line 7 , for this movement would reallocate all production to country $\mathrm{C}$, which has the highest social cost due solely to its failure to regulate effectively.

Line 13 depicts the outcome if countries $\mathrm{B}$ and $\mathrm{C}$ form a customs union

least damage, which often is in a developing country that places a higher value on economic development and income growth than on environmental quality. The point made by Summers and the political response to it provide extremely useful insights into why regulatory policy has become an important component of international trade negotiations. 
in which they each impose a tariff of 10 on each other but maintain a tariff of 25 against country $\mathrm{A}$, which $\mathrm{A}$ reciprocates. In this regime, country $\mathrm{C}$ exports to country B (inefficiently), and country A produces for itself (also inefficiently).

One can produce many other permutations of these results by assuming different regulatory regimes in different countries with respect to either the efficiency of their regulation or the extent to which external costs are internalized in market prices. As is apparent from the example, different combinations of regimes produce differences in the extent of international specialization. For example, suppose that country B regulates efficiently, with external cost fully internalized in the market price, but country $\mathrm{C}$ regulates inefficiently - and does not pursue a policy that causes external cost to affect price. In this case, the market price in B will be 120 , while the market price in $\mathrm{C}$ will be 104. During negotiations over dropping the tariff from 25 to 10 , country B will recognize that by doing so it is in danger of losing an efficient industry to country $\mathrm{C}$ and so may want to discuss regulatory reform in $\mathrm{C}$ as part of the trade negotiations.

The purpose of these examples is to demonstrate two crucial points. First, regulatory policy can have an effect on international trade that arises for either "good" (efficiency) or "bad" (regulatory inefficiency) reasons. Second, for either reason regulatory policy can emerge as a crucial part of trade negotiations. The differences in regulatory costs among nations arise from three sources: differences in compliance costs arising from a locally optimal policy, differences in total social costs and the extent to which external costs are reflected in market prices, and differences in the extent to which countries pursue the optimal regulatory policy. For trade negotiations to produce an improvement in the international allocation of resources, the causes of regulation-induced international specialization must be recognized and taken into account in the trade agreement.

\subsection{Rationalizing Regulatory Objectives and Methods}

The preceding discussion is based on the premise that some of the observed variation in the cost of regulation reflects inefficiency rather than valid policy objectives. All regulation carries the danger that it will reduce efficiency by increasing production costs without delivering offsetting social benefits; however, lax regulation can produce inefficiency by encouraging production that has low private but high social cost. In addition, all forms of regulation may further reduce economic efficiency by thwarting international competition, and especially the entry of firms into markets that are not competitive or that are served by inefficient incumbents.

A great deal of research on regulatory policy argues that in several important areas, regulation does impose unnecessary costs. If a regulation imposes costs but serves no valid social purpose, or more generally if regu- 
latory methods serve a valid purpose but are grossly inefficient, the consequence is an inefficient domestic economy. If a poorly performing industry's inefficiency is the result of government policies, the industry is likely to receive a sympathetic political response when it seeks protection against foreign competitors that face more efficient regulation and hence lower regulatory compliance costs. Consequently, domestic regulatory reform can complement liberalized trade and foreign investment policies.

Notwithstanding the presence of some unnecessary regulatory costs, international differences in the cost of regulation may reflect valid differences in circumstances among countries. For example, a given amount of emissions will cause different amounts of damaging pollution because of physical, ecological, and climatic differences among locations. Similarly, local differences in relative factor prices (including the shadow prices of environmental resources) can cause the cost of achieving a given amount of abatement to differ across locations. Likewise, the aesthetic benefits of pollution abatement are likely to exhibit a positive income elasticity of demand and so to be valued more highly in a wealthy nation than in a poor one. All three factors are a legitimate source of comparative advantage in international trade. In short, Lawrence Summers was right!

A regulation-induced trade effect is frequently mischaracterized as a "competitiveness" issue that involves the overall trade performance of a nation, as measured by the balance of trade or domestic unemployment in export industries. Industries that produce traded goods and that experience significant regulatory compliance costs correctly perceive that regulation has reduced their ability to compete with firms that are located in countries with lower costs of compliance. Regardless of whether a nation's high regulatory compliance costs reflect efficient or inefficient regulatory decisions, an industry that faces especially stringent regulations is likely to complain about the absence of a level playing field. In some cases, political leaders who are sympathetic to the industry may call for regulatory relief to improve the industry's competitive position. In other cases, the call may be for trade barriers against nations that have less stringent regulation. The latter position can be the basis for a coalition of trade-impacted regulated industries and environmentalists in which the latter are motivated by the desire to influence pollution in other countries.

As the preceding examples of the trade effects of regulation indicate, the economics of regulation-induced trade distortion is more subtle and complex than the competitiveness argument implies. Indeed, a nation's movement to more stringent regulation can be an act to level the playing field in the sense of eliminating indirect subsidies that take the form of unpriced overuse of environmental resources in production.

Even in the absence of trade, stringent regulation causes regulated products to be more expensive and thereby shifts the composition of domestic economic activity into other, less regulated activities. If all regulations, 
both stringent and lax, reflect efficient responses to real problems, this shift in the composition of production is desirable: on balance, it improves the economic welfare of a nation. But if some regulations are too stringent, or others are too lax, the pattern of regulation is harmful to national economic welfare. Under a liberal trade regime, the shift in the industrial composition of domestic output is even larger because exports displace domestic production for intensely regulated products, while domestic production displaces imports for less regulated products. If regulatory rules are efficient, the change in the pattern of trade is desirable. If regulatory rules are inefficient, the result is a trade distortion.

The most efficient regulatory and international economic policies are based on distinctions between inefficient regulation and valid differences in circumstances as causes of international differences in the costs of regulatory policies. Moreover, the appropriate conceptual model for guiding policy is that the social issues that give rise to regulation may cause efficient differences among nations in the stringency and implementation cost of regulation. The latter cost differences are valid sources of comparative advantage among nations, and policy should not try to level the regulatory playing field by making private compliance costs equal in all nations. Instead, the right policy is to let trade reallocate activity to low-cost sources of supply. A nation that has especially valuable environmental resources, or that places an especially high value on avoiding illness and injuries, is better off if it adjusts the composition of its economy away from activities that lead to pollution or poor health.

Constructing an efficient trade regime, then, requires taking into account the efficiency of regulatory regimes. Consequently, regulation inevitably is part of the optimal trade regime, and regulatory reform a part of negotiating trade arrangements. If nations differ in the efficiency of their regulatory regimes, completely free trade will cause distortions of trade and a departure from the allocation of production according to comparative advantage. Hence, pursuit of free trade requires incorporating evaluations of each nation's regulatory policy and the possibility of negotiating regulatory reform in parallel with trade negotiations. If a domestic industry raises the competitiveness issue with respect to the cost of domestic regulation, the appropriate response is, first, to ascertain whether the firm really is overregulated relative to the social cost of its activities; second, to determine whether foreign competitors are underregulated by the same criteria; and, if the answers to these questions are no and yes, respectively, to address the problem by seeking to improve regulatory performance in the other nation.

\subsection{Economic Analysis of Regulation}

The first step in designing an efficient combination of regulation and trade policies is to distinguish between valid and excessively stringent or 
lax regulation and between effective and ineffective instruments for dealing with the problems that regulation is intended to solve. Economic analysis provides a means for identifying whether regulation as practiced comes reasonably close to meeting the standard of economic efficiency. By presenting a clear statement of the problem to be solved, the theoretical objective of a policy intervention, and the performance characteristics of the available policy instruments, economic efficiency analysis provides a coherent analytical method for assessing the basis for differences among nations in the costs of regulatory compliance. This section outlines the state of knowledge about the rationales for regulation and instrument choice, as well as some observations about how these issues relate to trade. ${ }^{5}$ In cases where regulation is warranted, economic efficiency analysis identifies cost-effective methods of regulation and, therefore, is a useful tool to assist nations in harmonizing regulations so that they are not trade distorting and are compatible with liberalization of trade and foreign investment.

The economic analysis of regulation focuses on market failure. Market failure occurs when private transactions do not reflect the social costs and benefits of an activity. Markets are an efficient method for organizing production and distribution when the number of buyers and sellers is large, when buyers and producers are reasonably informed about the consequences of making and producing a product, and when all of the benefits and costs of producing and consuming a product are experienced only by producers and consumers. Market failure arises when a market departs significantly from any of these characteristics. The three types of market failure are imperfect information, externalities, and monopoly. A fourth market failure, ruinous competition, has been alleged but has been found to be an empty vessel. The latter two failures are the primary basis for economic regulation, or the regulation of prices, profits, and entry. The first two form the primary basis for social regulation, such as controlling pollution, improving the safety and healthfulness of products and workplaces, and requiring full disclosure of the characteristics of products.

The regulatory policy debate often focuses more on income inequality and other aspects of distributive justice than on market failure and efficiency. Contrary to the belief of many noneconomists, economic analysis is not inherently devoid of concern about distributive justice. In particular, if individuals care about distributive justice, then the effects of policy on distribution are a form of externality that, in principle, can be taken into account in policy analysis and instrument design. Economic efficiency analysis of regulatory policy can and has focused on three core distributive issues: the actual distributive effects of regulation, the role of income effects in determining evaluations of regulatory policies, and the relative effectiveness of regulation in dealing with distributive concerns. In eco- 
nomic regulation, the primary distributive justice issue is access to core infrastructural services, such as water, electricity, and telephones, and arises in the context of "universal service" policies. In social regulation, the "Lawrence Summers problem" described above has an analogue in the idea of uncompensated reallocation of waste to communities that either have a low willingness to pay to avoid the reallocation or that lack political influence, causing their preferences to be ignored in decisions about waste disposal. ${ }^{6}$

\subsubsection{Economic Regulation}

Ruinous competition is a condition in which a competitive industry engages in price wars that bankrupt the participants or that cause wild, unpredictable price swings that prevent buyers from being able to rely on price predictability. Much of the regulation and nationalization enacted during the 1930s, such as in trucking, airlines, hydrocarbon fuels, and, in some countries, manufacturing industries, was based on the belief that the Great Depression was caused by excessive price cutting in competitive markets. Privatization and economic deregulation of these industries in several countries has generated considerable evidence that competition is efficient, regulation or nationalization is unnecessary and inefficient, and the ruinous competition argument is simply wrong.

In the United States, economic regulation was either removed or substantially relaxed in industries accounting for approximately 10 percent of gross domestic product. Recent assessments of the magnitude of the annual economic benefits of these changes (primarily in the form of lower prices to consumers) are $\$ 5$ billion for airlines, $\$ 8$ billion for trucking, and $\$ 3$ billion for natural gas (Winston 1993). In Australia, deregulation reduced prices 20 percent in airlines (OECD 1996c). Privatization of nationalized airlines produced welfare gains equal to 1.6 percent of sales for British Airways, 22.1 percent of sales for Malaysia Airlines, and 48.5 percent for Aeromexico. ${ }^{7}$

Regulating industries that could be structurally competitive is certainly costly to the domestic economy, but it can distort trade as well. To the extent that these regulations apply to services used by export industries, they raise costs and distort both exports and imports. An especially good example is the regulation of international transportation, which has not been relaxed as rapidly as domestic regulation. Inefficient regulation of

6. Discrimination, whether in employment or product markets, can be conceptualized as a form of externality that can be dealt with by regulatory means. Whereas discrimination against foreign workers is a major issue in trade policy, its analytics are sufficiently different from other forms of market failure and regulatory intervention that it is not analyzed in this chapter.

7. Galal et al. (1994). For a thorough summary of the literature evaluating privatization activities around the world, see World Bank (1995). 
international transportation has three distorting effects. First, it reduces trade in transportation services by raising its price and imposing rules that guarantee a minimum market share to domestic firms. Second, it reduces the extent of beneficial international specialization in other products as excessive transportation prices drive an unnecessary wedge between domestically produced goods and their foreign competition. Third, transportation regulation distorts input choices among transportation firms in ways that affect trade, such as by creating pressures to favor domestic equipment manufacturers and by insisting on inefficient route structures based on arbitrary distinctions between foreign and domestic terminals.

Another rationale for economic regulation of competitive industries is based on the assertion that a particular form of firm or choice of technology has a cultural externality. Examples are preserving democracy, a nation's cultural identity, small business (retail shops, family farms, etc.), social cohesion between rural and urban communities (through crosssubsidies for infrastructural services), or excess capacity and control in case of natural disaster or war. Some examples of this line of argument are claims that, say, foreign branches of Disneyland and McDonald's, or foreign distribution of movies and recorded music from the United States, are a form of American cultural imperialism.

These rationales are difficult to assess, for they are tautological: they define the national interest as the present market structure. In many cases, these rationales seem to be a relatively transparent excuse for protection and cartelization. The point of this form of economic regulation is not just to subsidize some users and providers but to do so by elevating prices to others, rather than by implementing a direct, targeted subsidy with a broad tax base, which is almost always a far more effective approach in the sense that it can achieve the objective of the policy at minimal social cost.

As is the case for regulations motivated by the ruinous competition rationale, economic regulation of competitive markets for the reason of cultural externalities is extremely costly. For example, in some countries retail trade is regulated by controlling entry, setting a maximum store size, and limiting shop hours, either through local zoning or national law. These regulations undermine competition by encouraging cartelization and reduce productivity by causing shops to be too small and underutilized. In the nations with the strictest regulations, Italy and Japan until reforms began in the $1990 \mathrm{~s}$, the number of retail outlets was roughly double the number that would be expected on the basis of other market characteristics. $^{8}$

Another example of this form of regulation is to serve the goal of uni-

8. OECD (1992). Since the time of this study, Japan has begun liberalizing retail trade. See also Baily (1993), who finds that labor productivity in retail trade is twice as high in the United States as in Japan. 
versal service in telecommunications and transportation by creating elaborate regulations (and in some cases a monopoly) that subsidizes rural areas by setting prices equal to average cost over a broad, heterogeneous geographic area-sometimes an entire nation-and requiring firms to serve high-cost areas as a condition of serving low-cost areas. The latter policy forces the regulator to define the boundary of a firm on the basis of the feasibility of a balanced cross-subsidy system rather than operating efficiency. Privatization, competition, and deregulation in long-distance telephony, trucking, and airlines all have been opposed on the grounds that the consequence would be denial of service to rural communities as well as on the basis of the ruinous competition argument.

The propensity to regulate retail trade and to create regulated firms of inefficient scope in communications and transportation to facilitate rural cross-subsidization could be an unfortunate precedent for the rise of electronic commerce.

The argument for protecting small shopkeepers from competition by department stores or discount retail outlets can easily be applied to electronic commerce, which is a similar innovation for increasing the convenience and reducing the cost of acquiring consumer goods. Whereas retail shop laws have had international ramifications, such as indirectly preventing successful retail chains from entering some countries, the international implications of restricting electronic commerce are surely more important. Both large department stores and discount retailers still must be physically accessible to their customers, so to the extent that there is an international ramification, it pertains to physical investment by a foreign retail chain. For electronic commerce, physical propinquity is unnecessary; a foreign retailer need not invest-or even set foot-in a country to be successful in selling goods. Hence, regulations to restrict electronic commerce, if pursued, are very likely to be a source of major trade distortions as well as international conflict.

Likewise, the universal service argument can and has been extended to insist that consumers in remote communities should be provided with Internet access, regardless of the cost of doing so. In the United States, the Telecommunications Act of 1996 states that any service enjoyed by over half of the population, or any other service so designated by a special universal service commission, is to be considered a universal service to be offered to everyone at a price equal to approximately the nationwide average cost. In the United States, the regulator - the Federal Communications Commission (FCC) - has been given the task of figuring out a way to achieve this goal while at the same time promoting competition and, eventually, deregulation in all aspects of telecommunications service, including local access. But the U.S. policy is unusual, and perhaps infeasible. More commonly, the universal service objective is regarded as requiring extensive regulation of both prices and the scope of a firm's operations. 
Regardless of the validity of cultural externalities as market failures, some of these objectives usually can be attained more effectively by direct subsidy or procurement by competitive bidding than by regulations that attempt to achieve them by elevating prices and preventing competition. For example, one means to assure transportation or communications services to remote communities is to introduce competitive bidding for providing service, where the franchise specifies price and service quality and requires that all customers be served who seek service at the price, subject to penalties for noncompliance. The subsidy can be provided from general revenues (as was enacted as part of airline deregulation in the United States, although the subsidy soon disappeared because small cities did not lose service), or through a tax on sales by all firms in the industry (as is the approach of the FCC in providing a fund to subsidize universal telephone service). Many public objectives can be accomplished more cheaply, with less distortion, by resorting to the procurement model rather than regulation.

If the procurement model is adopted, the trade distortions caused by this form of regulation can be reduced. Foreign suppliers can submit the low bid to supply subsidized service, and if they are still denied the contract, the trade-distorting purpose of the regulation is exposed and can become an issue for international dispute resolution and negotiation.

Monopoly can arise from mergers, unfair trading practices, or regulatory entry barriers, in which case the cure may be simply to promote competition. Economic regulation can make sense only if the monopoly is natural, that is, if the technology underpinning the industry is such that only one firm can serve a market at minimum cost.

The rationale for most economic regulation, especially in utility industries such as communications, electricity, and water distribution, is the presence of natural monopoly somewhere in the industry. For natural monopoly to justify a regulated or nationalized monopoly, regulation or nationalization must not cause even greater inefficiency than an unfettered market. In the 1980 s, two types of research findings called into question both assumptions. First, studies found little or no evidence of scale economies in many segments of supposedly natural monopolies. ${ }^{9}$ Second, countries that allowed competitive entry and engaged in less restrictive regulation had lower prices and more productive industries. For example, relaxation of regulation in railroads and telecommunications in the United States saved consumers over $\$ 2$ billion annually (Winston 1993). International comparisons find that productivity in the utility sector is substantially higher in countries with more liberal policies (Baily 1993). In partic-

9. See Nelson and Primeaux (1988), which finds that scale economies are small enough that they are offset by the efficiency advantages of competition in about forty U.S. cities that have competing utilities, and Bernstein (1988), which finds no significant scale economies in telephone service. See also the references in these papers. 
ular, when combined with policies to facilitate transactions among retail electric utilities, free entry and almost complete deregulation in electrical generation is feasible and offers considerable cost savings. In the 1990s, over half of new generation facilities in the United States are expected to be constructed, owned, and operated by independent power producers (Utility Data Institute 1992).

Regulated monopoly produces inefficient operations for two fundamental reasons. First, historically prices in regulated monopolies have not been set in a manner that encourages monopolists to be efficient. For private monopolies, prices typically were set equal to some measure of average cost. Because as monopolies these firms had unexploited market power, increases in costs could be passed through to customers. Second, regulated monopolies, whether private or public, were regarded as a means for serving many political purposes other than providing efficient, fairly priced service. Among these purposes was subsidizing favored constituencies (including the government itself). For nationalized monopolies, another purpose was generating revenue for the government as public officials saw tariffs as taxes, rather than prices, to be allocated as part of general government revenue. ${ }^{10}$ All of these policies served to decouple prices from costs and to distort if not destroy the incentives of the firm.

Because regulation has created inefficient operation, the case for stringently regulating even firms with natural monopoly characteristics has been seriously questioned. For example, if in an unregulated state an industry is likely to be a relatively concentrated oligopoly, it is plausible that deregulation will produce lower prices and better quality (by sharpening incentives) than regulation, even if the latter succeeds in producing a seemingly better ratio of price to average cost.

If economic regulation is retained because an incumbent's market power is likely to be substantial and durable, the agenda for regulatory reform contains two items. The first is to adopt regulations that give firms sharper incentives for reducing costs. The second is to identify the specific elements of an industry that are most plausibly a durable monopoly, and to adopt policies to assure that practices in these monopolized markets do not impede competition and reduce efficiency in other markets.

In the first category of reforms are "price cap" regulation and "earnings sharing" regulation, both of which allow regulated firms to keep some of the profits from improved efficiency." The alternatives to incentive regulation are either cost-based price regulation or prices that are set by elected political officials, such as by inclusion in a statute, with no necessary connection to costs or market conditions. The difficulty with the first approach

10. For a discussion of the operations of nationalized telephone companies, see Noll (forthcoming).

11. For an excellent review of incentive regulation, see Baron (1989). 
is that it rewards inefficiency by increasing allowed prices in proportion to costs. The problem with the second is that extreme politicization of prices almost always leads to massive financial losses, which are then matched by subsidies. Price-cap and earnings-sharing regulation begin with a set of prices that allows the firm roughly to break even, but to keep part of the profits it derives from cost reductions. Price-cap regulation also gives the firm flexibility to change prices as long as, according to an averaging formula, prices generally do not increase.

Telecommunications in the United States provides a useful laboratory for assessing the effects of incentive regulation. Prior to reform, the U.S. telecommunications industry was a monopoly regulated on the basis of cost-based pricing and was generally regarded as among the most efficient in the world. Nevertheless, in an attempt to improve efficiency, parts of the industry were opened to competition. The parts that were regarded as insufficiently competitive to allow deregulation were regulated by many different regulatory jurisdictions, both federal and state, and these regulatory authorities have adopted several different forms of price regulation. The results of recent research indicate that price-cap regulation has substantially increased the rate of productivity advance (Majumdar 1995) and has led to lower prices (Crandall and Waverman 1996, 213-15) and to more rapid diffusion of new technology, such as digital switches, advanced signaling, and ISDN lines (Greenstein, McMaster, and Spiller 1994).

The second category of regulatory reform attempts to minimize the extent to which regulated monopolies leverage their market power by gaining an undeserved advantage in markets that are vertically related to the monopoly, but that can be competitive. Examples are equipment sales to regulated monopolists and products for which the monopoly service is an important input. Here policy reforms include proactive intervention by competition policy agencies to scrutinize regulations for anticompetitive effects; "equal access," "equal interconnection," and "open bidding" requirements so that affiliates of the monopolist are not treated differently than their independent competitors; and "separations" requirements for unregulated activities of regulated firms. ${ }^{12}$

In telecommunications, several countries have successfully segmented the industry and introduced competition into several components. In most nations, equipment manufacture has been separated from services, although a "national champion" manufacturer usually still commands a large share of sales to telephone service companies, abetted by regulatory procurement practices. In many countries, radio telephony is somewhat competitive and is offered by firms other than monopoly wireline access

12. For a discussion of which circumstances do and do not plausibly require separations in order to introduce competition into a vertically integrated regulated monopoly, see Joskow and Noll (1999). 
providers. In some countries, long-distance entry has been permitted and is successful. And a very few countries-India, New Zealand, the United Kingdom, and the United States-have not only permitted but have tried to encourage local wireline access competition, but with limited success.

In all of these cases, a major issue has been how to prevent a firm that enjoys a monopoly in one segment from leveraging that monopoly to achieve market power in other segments. For example, a competitor in long-distance or radio telephony must deal with wireline companies (usually monopolies that are either regulated or state owned) in order to complete its calls. If the wireline monopoly also provides competitive services, it can increase its market share in these services by raising the price or lowering the quality of service to its competitors. Inevitably, attempts to introduce competition into telephony have led to charges by entrants that incumbent vertically integrated firms engage in precisely these practices. One approach, vertical divestiture, has been tried in a very few countries, most notably the United States and Chile. Most countries have relied instead on regulation or competition policy to enforce nondiscriminatory behavior by the incumbent.

In several countries, competition also has been introduced in segments of the electric utility industry that had been dominated by vertically integrated monopolies. ${ }^{13}$ One success apparently is in Norway, which created a separate state-owned power pool, Statnett Marked, to manage bulk power sales across the territorial boundaries of regional electric utilities. This reform appears to have substantially increased transactions and narrowed price differences for electricity among regions. Similar experiments in California, the eastern United States, England, Sweden, and Australia have introduced competition in generation, retail sales, or both (see Joskow 1998).

Few countries have tried any degree of vertical divestiture in electricity. The exceptions are the creation of two generation companies in England and Wales and a policy to favor nonutility companies in building new generation capacity in parts of the United States. Complete vertical separation between generation and transmission has not been mandated anywhere. Instead, governments have attempted to create "independent service organizations" that manage access to the transmission grid, including regulating the price of transmission services as well as determining the rules for independent generation sources to use the network to deliver power to their customers. This approach essentially separates the ownership of transmission networks from their management and operation.

Regulatory reform has faced difficulty in preventing regulated monopolies from dominating vertically related, potentially competitive markets.

13. For an excellent summary of several of these cases, including England, Norway and Sweden, and Australia, see Wolak (chap. 3 in this volume). 
In the United States, policies to protect against vertical leveraging have given rise to persistent conflicts before regulatory agencies and antitrust courts for nearly a century (see Noll 1995; Joskow and Noll 1999). In the United Kingdom, which did not adopt separations remedies in telecommunications but did so to a limited degree in electricity, subsequent evaluations concluded that competition has not been extensive and intense (see Wolak, chap. 3 in this volume; Armstrong, Cowan, and Vickers 1994, esp. 355--58).

In the vast majority of the world, firms in the sectors where the natural monopoly argument is most commonly thought to apply have been stateowned enterprises. But beginning in the 1980 s, several countries privatized formerly public enterprises, either as a reform measure that was an end in itself or as part of a plan to introduce competition. These experiences provide useful information about the comparative efficiency of the two organizational forms.

A recent study of generation facilities that account for over 40 percent of the world's capacity finds that private utilities produce electricity at about 5 percent lower cost than public enterprise utilities (Pollitt 1993). A study of privatization in Britain finds efficiency gains of 12 percent for British Telecom, 4 percent for National Freight, and 1.6 percent for British Airways (Vickers and Yarrow 1988). A study of British Gas concludes that privatization increased productivity by 2.3 percent; however, inconsistent results for a productivity effect were found for the regional electric utilities (Button and Weyman-Jones 1994a, 1994b). A study of privatization in Chile and Mexico found increases in economy-wide economic benefits of 50 percent for Telmex, 155 percent for Chile Telecom, and lesser but positive benefits for other cases (Galal et al. 1994). Even some urban water systems in developing countries, such as Abidjan, Buenos Aires, and Santiago, have been successfully privatized (Noll, Shirley, and Cowan forthcoming).

The lessons from reform of economic regulation in many nations are as follows. First, substantial gains in efficiency can be captured from improving the institutional environment of regulated infrastructural industries, such as by privatizing nationalized companies and adopting incentive regulation. Whereas these reforms provide direct domestic benefits in the form of lower prices for consumers, they also remove a trade distortion in that they lower the costs of export industries that make intensive use of the services of infrastructural monopolies. Second, because the case for natural monopoly is problematic, eliminating entry restrictions can introduce still greater efficiency.

These conclusions have important international ramifications. Because in many infrastructural industries only one firm has been allowed to offer service, the most plausible entrant is often the entrenched incumbent in another nation. In developing countries, privatization almost always in- 
volves at least partial ownership by a foreign company in the same industry, and other such firms have almost always been the most common source of competitive entry. In addition, in all of these industries national boundaries do not provide a basis for reasonably differentiating markets or the scope of a firm. In transportation and telecommunications, international services are arranged through mutual agreements between nations and their designated companies, and in electricity, regional power pools in Europe and North America extend across national boundaries. In these cases, formal separation of market access based on national boundaries is inefficient and precludes competitive entry by the firm that most plausibly could extend service in a monopoly service area at lowest cost. Hence, mutual relaxation of foreign investment restrictions by adjacent trading partners is a promising mechanism for speeding the evolution to competition after formal monopoly franchises have been removed.

The voluntary WTO agreement regarding access by foreign telecommunications firms is a good illustration of the connectedness of international economic policy and domestic regulation. Signatories to the agreement have committed to open at least international calling and in some cases elements of domestic service (such as long distance within the country), in most cases by the year 2000. Twenty nations have gone so far as to commit to a "single market" in telecommunications, allowing firms in these countries access to all twenty.

\subsubsection{Social Regulation}

Environmental protection is an example of regulation to deal with externalities. In this case, regulatory reform means, not deregulation, but the use of more flexible methods of regulation. In almost all countries, the standard method of regulating pollution is to set technical standards for each source. ${ }^{14}$ These standards often are more rigorous for new production facilities than for established enterprises and so distort market entry. The stringency and cost of standards also vary among industries, further distorting the pattern of economic activity to favor less rigorously regulated sectors. For example, a study of sulfur oxide emissions in Los Angeles found that the marginal cost of abatement for the most heavily controlled sources (electric utilities) was $\$ 20,000$ per ton, whereas other controlled sources faced marginal costs of abatement of around \$200 (glass bottle manufacturing), and still other sources remained completely uncontrolled (dry cleaners; Hahn and Noll 1982).

Technical standards have led to two important sources of trade distor-

14. For an excellent review of the status of environmental regulation worldwide, see Hartman and Wheeler (1995). For an assessment of the tenacity with which the United Kingdom has clung to source-specific standards for environmental regulation, see Helm (1998). 
tions. First, because such standards almost always specify the technique that must be used to reduce emissions, the standard itself can be a barrier to trade by ruling out other approaches to compliance that may be as effective but are not consistent with the standard. Second, by causing differences in compliance costs among sources within the same industry, technical standards actually can inefficiently induce imports. For example, by driving a wedge between old and new emission sources, new source performance standards create a discrete jump in the marginal private cost of production in an industry when increased production means expansion of capacity. If import prices are between the marginal costs of production at old and at new facilities, the effect can be to encourage imports to satisfy new demand, whereas efficient regulation would allow new firms to enter successfully at a price below the import price.

Because progress in environmental protection has been slow while compliance costs often have been high, some nations have begun to experiment with the use of economic incentives rather than technical standards. The two primary methods for achieving greater efficiency by introducing economic incentives into environmental regulation are emission trading and effluent fees. The advantage of both is that they are competitively neutral among industries and firms.

Emission trading in the United States began in the late 1970s with "controlled trading options" for six air pollutants, whereby two or more sources could propose regulations that reallocated pollution among them, subject to many procedural requirements and technical constraints. Despite a burdensome process, this program saved at least hundreds of millions of dollars, and more likely billions, in compliance costs without reducing environmental quality (Hahn 1989). Later, in Singapore and the United States, emission markets were used to meet international commitments under the Montreal Protocols to reduce chlorofluorocarbon emissions. In the United States, emission allowances were allocated according to historical production, but emitters were permitted to buy and sell allowances. In Singapore, emission allocations were sold at auction (O'Connor 1991). Another example is "offsets" in Germany and the United States, whereby new sources of pollution in a heavily polluted area are not permitted unless emitters reduce emissions from other facilities by more than the amount of emissions created by the new facility (Hartman and Wheeler 1995).

Effluent fees are a tax on the emission of harmful pollutants. The textbook model of effluent fees is to set the tax high enough to reflect the damage created by pollution so that polluters have a financial incentive to abate if pollution abatement is less costly than the harm it creates. Although many countries set effluent fees, these fees are almost never high enough to create a significant financial incentive to abate. Sometimes fees 
are selectively imposed because too few resources are allocated to enforcement or because politics enters into decisions about how much tax to levy on each source of pollution. ${ }^{15}$

In a few cases, effluent fees are reasonably effective. One example is water pollution control in the Netherlands (Anderson 1994; Hahn 1989). Water effluent fees are much higher in the Netherlands than elsewhere and so induce much more abatement at the source, thereby more closely approximating the least cost division of responsibility between source controls and sewage treatment. In Japan, effluent fees for sulfur dioxide emissions provide a fund for compensating victims of unhealthful air pollution (O'Connor 1993). Whether these fees are adequate is debatable, but the principle that polluters pay for the damage that they create motivates the fees.

The international consequence of incentive-based environmental regulatory reforms is to reallocate production among nations in a manner that reduces total social costs. These reforms reduce compliance costs for industries that need to control harmful pollutants. As a result, the relative production costs in these industries fall compared with firms in nations that use less efficient methods of controlling emissions, and if their products are traded, these industries gain a larger share of the world market. In some cases, the principal effect is that domestic production substitutes for exports that appeared attractive only because they were produced in a less costly regulatory environment. In other cases, the principal effect is to increase exports among industries that experience lower regulatory compliance costs. In all cases, all prices and exchange rates adjust so that some other industries experience some compensating adjustment in net imports, and total trade can either rise or fall. But in all cases, the net effect is an increase in world productivity and income as production moves in response to reductions in social costs.

Another international implication of incentive-based environmental regulation is that it beneficially affects location decisions of international firms. The relative anonymity of incentive-based environmental reforms eliminates the possibility that environmental standards will be applied in a discriminatory fashion against foreign investors. Because entry requires only that the new facility buy permits or pay emission taxes, rather than receive an emission standard and a permit to operate, incentive-based environmental regulation eliminates a source of regulatory barriers to entry.

Regulations that deal with information imperfections are called protective standards. This category of regulation is broad and heterogeneous. It includes product safety, drug efficacy, workplace safety, prudentiality in financial services, and protection against fraudulent advertising and prod-

15. E.g., Poland's effluent fee system appears not to have worked for these reasons (Wilcynski 1990). 
uct labeling. At the heart of such regulations are two basic concerns. One is that one side of a market-consumers or workers-has less access to information about the quality of the product or workplace than the other side and so might be victimized. The other concern is that neither side of the market will have an adequate incentive to acquire valuable information that would be useful for evaluating products and workplaces, and that, if known, might change behavior and hence product and workplace safety.

As with environmental regulation, the issue in protective regulation is not whether such regulation is ever justified but how best to achieve regulatory objectives more efficiently. Protective standards can cause several economic problems. First, they can retard beneficial technological change by introducing inflexibility in designing products and workplaces. Second, they can prevent informed decisions that reflect individual differences in attitudes about or susceptibilities to risk. Third, they create a process that can be used by producers to create barriers to competition, especially international market access.

Reform in this area of regulation takes many forms, depending on the nature of the problem. One reform is to require full disclosure, backed by documentation of claims, so that the uninformed side of a market has more information, and then to let the market determine the appropriate degree of risk. Another reform is to adopt international standards processes so that a consumer product or workplace equipment need only prove its acceptability once, rather than separately in each country. Still another approach is to focus on performance standards rather than design standards. Performance standards allow greater variety in technical approaches to solving the same problem and so encourage cost minimization and technological progress. Finally, another approach is to subsidize product testing by independent authorities (governmental or private) and to publicize the results.

A recent OECD survey indicates that most firms in four industries (toys, lawn mowers, microwave ovens, and bicycle helmets) regard the present standards system as excessively cumbersome and costly, and about onethird indicated that some national standards processes prevented them from entering markets, even though they had satisfied equivalent standards elsewhere (OECD 1996a). The purpose of reform is to avoid these effects when they have nothing to do with the protective purposes of regulation.

\subsection{Priorities for Reform}

The preceding analysis focuses on specific types of regulations and institutional reforms and by implication constitutes a long list of areas in which literally every nation can find useful examples from other countries about how to make regulation more cost-effective. This section focuses 
on the international implications of three categories of regulatory reform: competition policy, procedural requirements such as mandatory benefitcost analysis, and internationalization of reform. All of these policies are closely related to the efficiency concepts discussed in this essay. In the absence of any of the market failures discussed here, an unregulated competitive market is efficient.

Many hypothesized market failures that underpin regulatory policy are illusory or unimportant, in which case regulatory reform means abandoning regulation and undertaking a vigorous policy to promote competition. The presence of a significant market failure provides a rationale for continued government intervention but does not require sacrificing either competitive markets or economic efficiency. In these cases, regulatory interventions will be most effective, first, if they focus narrowly on curing the market failure while minimizing the extent to which they disrupt competition and, second, if these interventions are designed to achieve their policy objectives efficiently. Hence, even when regulation is present, there is usually a heightened role for competition policy: to assure that regulation disrupts competition to the minimum extent necessary to cure the market failure. And to help identify the most cost-effective ways to attack market failures, regulations should be developed with the aid of a comprehensive economic impact analysis.

Because regulation has become more important as a source of trade barriers, domestic regulatory policy has become a major agenda item in negotiations over trade policy. Internationalization of regulatory reform is viewed with skepticism and alarm by some advocates of liberalized trade, partly because the result of international regulatory negotiations can be the formation of an international cartel beyond the reach of domestic reform. Historical agreements about international telephone and airline services stand as continuing reminders of the pitfalls of international regulatory agreements.

Notwithstanding these problems, internationalizing regulatory policy also can facilitate the reform process and provide additional insurance against backsliding. The arena of international trade negotiations provides an opportunity for expanding the benefits of domestic reforms by pairing them with foreign reforms that grant domestic firms greater access to external markets. Once agreement is reached, international trade enforcement institutions, such as the WTO and the European Court, provide additional protection against subsequent regulatory actions that distort trade.

\subsubsection{Competition Policy}

Policies to promote competition are always in some tension with regulation, and effective regulatory reform usually requires rethinking how this tension should be resolved. The essence of the tension is that regulatory 
policy promulgates common rules of behavior for firms within a market and sometimes encourages monopoly or cartels, whereas competition policy seeks to eliminate monopoly and to force firms to operate independently. Fixing a price or a common production technology through a regulatory process is far different conceptually from insisting that each firm make price and production decisions separately and letting the competitive process determine the ultimate performance of the industry.

The anticompetitive danger of regulatory policy arises from the fact that it asks a regulatory authority to make decisions normally made by firms engaged in competition. Consequently, the power to regulate can be abused by a group of participants in a market if they can make use of the regulatory process to reduce competition among themselves, at the expense of other groups in the market. For example, a regulatory standard may reduce pollution, improve product quality, or make the workplace safer, but it may also do none of these things but instead simply require that consumers buy one type of product rather than another, benefiting the producer of that product at the expense of competitors and consumers.

Regulation often has served anticompetitive purposes by favoring domestic products over imported ones, thereby creating an indirect trade barrier. As discussed above, one example from the United States is policy regarding reformulated gasoline, whereby the details of the regulation required Venezuelan refiners to make greater improvements in their product than were required of U.S. producers of equivalent gasoline (Vogel 1997). Another example is the requirement in many countries that suppliers of infrastructural services - telephones, electric power, transportation, and so forth - be domestically owned.

Certainly the presence of these examples implies that parallel distortions in the politics of trade policy are plausible. Regulators seek to give domestic producers the advantage partly because foreign producers are less likely to be effective participants in the domestic political process, and so are less likely to be important sources of political support or opposition to a government. Indeed, not only are the employees and owners of an excluded foreign firm denied the vote, in most countries any attempt by foreigners to influence domestic politics is regarded as a criminal offense.

A second cause of regulatory favoritism toward domestic firms is that most debate about regulatory policies is narrowly focused on a particular industry, problem, or even detailed regulation. Even if a statute or an international treaty expresses the objective of avoiding anticompetitive regulations, anticompetitive outcomes are difficult to avoid if regulation inevitably arises from product-specific or industry-specific debates. Specific regulations require detailed analyses of the nature of the problem giving rise to regulation and its possible solutions. The process of undertaking such an analysis favors domestic industries: politically because they can apply direct political pressure to regulators and procedurally because they 
have standing before the regulators and possess information needed to assess the benefits and costs of regulation. An excluded foreign firm is unlikely to have the right to participate in these processes, and the domestic interest that would benefit from competition-buyers of regulated products - is unlikely to find it worthwhile to pay the cost to participate in the process as an advocate of foreign competitors. This problem is by no means limited to potential foreign competitors. In many cases, no firm that is not already a supplier in the industry has rights of participation in the regulatory process. Such was the case in airline regulation in the United States before deregulation (see Breyer 1982, esp. chap. 16) and is the case in telecommunications regulation in Japan (see Noll and Rosenbluth 1995).

The anticompetitive use of regulation, whether against domestic or foreign competitors, is common enough that it has been given a name: "regulatory capture." This term has an unfortunate connotation of corruption, whereby regulators consciously act on behalf of one economic interest at the expense of others and to the detriment of the economy. Whereas in some cases regulation has served as little more than a means for creating a monopoly or a cartel where otherwise competition would reign free, more subtle forms of capture probably are more important. Regulators must adopt regulations on the basis of the information available and the proposals made to them. All too often a particular regulatory issue does not capture the attention of anyone other than a few companies affected by it. If these companies propose a regulation that will reduce competition and increase their profits, the regulator may not recognize the fact or may not have enough information to ascertain whether a less anticompetitive regulation is feasible.

Competition policy can play an important role in limiting the extent to which regulatory policy has unnecessary anticompetitive effects. For example, an agency responsible for competition policy can systematically review important pending regulatory proceedings and provide its views about the effects of alternative regulations on competition. A competition policy agency also can bring actions against companies that use the regulatory process for anticompetitive purposes, as in the watershed antitrust case against the American Telephone and Telegraph Company in the United States. ${ }^{16}$

Regarding economic regulation, the introduction of competition into formerly monopolized infrastructural industries has raised important questions about interconnections between established firms and competitive entrants. When regulation prevents a monopolist from exercising full monopoly power in regulated markets, a strong incentive is created to le-

16. For details about this case and its interaction with U.S. regulatory policy, see Noll and Owen (1994). 
verage the regulated monopoly into competitive areas. The means that incumbent monopolists have used to accomplish this objective are to deny competitors access to monopoly services that are essential parts of competitive services and to engage in abusive conduct, such as price discrimination, predatory pricing, or degradation of service, to undercut the success of a competitor (OECD 1994a).

In the environmental, health, and safety area, regulatory standards can create entry barriers and can facilitate the formation of cartels. For example, collaborative recycling arrangements sometimes are attractive for capturing economies of scale and coordination among manufacturers, but they can also give firms opportunities for coordinating pricing and production behavior (OECD 1994b). Likewise, product standards that differ very slightly among countries can serve solely to protect a domestic market for a single supplier, as the EEC Commission concluded in reviewing a herbicide regulation in Germany (OECD 1995a, 10-11).

When the anticompetitive policies of regulators exclude domestic suppliers, competition policy agencies have a domestic political constituency that will support their intervention; however, if regulation mainly excludes foreign competition, foreign interests face the same political liabilities in influencing both competition and regulatory policies. Their lack of effective political representation is as likely to affect one bureaucracy as another. But dispute resolution institutions created to enforce trade agreements can serve this function. These entities can be the international counterpart to domestic competition policy agencies if international agreements give them the authority to examine whether regulations anticompetitively exclude foreigners.

\subsubsection{Procedural Reform: Mandatory Economic Policy Analysis}

Procedural reform refers to a variety of proposals for improving the quality of regulation by improving its structure and procedures. Examples of such reforms are changes in rights of standing before regulatory authorities, the burden of proof, the standard of proof, the nature of judicial review, and the place of the regulatory authority in the hierarchy of government agencies. The structure and process of regulation are important determinants of the three major aspects of regulatory outcomes: stringency (how tough is the regulatory requirement?); equity (how are the burdens and benefits of regulation allocated across industries, geography, and demographic categories?); and efficiency (does the regulation achieve its purposes at lowest possible cost?).

The structure and process of regulation are important because they affect the flow of information both in the regulatory process and to citizens about the basis for a regulatory rule. In essence, structure and process determine the relative weights given to different interests and types of information in making regulatory policy (McCubbins, Noll, and Weingast 
1987, 1989). An important purpose of structural reform is to improve the efficiency of regulation by making the process more open and transparent.

A prominent example of procedural reform is to require some form of economic policy analysis, which refers to a range of analytic methods for evaluating policies. The most common form is benefit-cost analysis; related methods include comparative risk analysis and cost-effectiveness analysis. The issue at stake is the extent to which economic policy analysis should play a role in the process of developing new regulations and regulatory policies.

The purpose of economic policy analysis of regulatory proposals is to provide a systematic framework for organizing relevant information for informing decisions, and to provide insight about the extent to which regulation is consistent and coherent across different areas of regulatory policy. A major criticism of regulation is that lessons from one domain of regulation are slow to spill over into others, and that different regulations, adopted at different times by different regulators, that deal with similar issues take vastly different approaches.

One study of 185 different regulatory proposals in the United States for improving health discovered no correlation between the cost-effectiveness of a proposal for saving lives and whether it was implemented (Tengs and Graham 1996). For example, this study points out that the existing standard for regulating the flammability of children's clothing has a cost of $\$ 1.5$ million per life saved, but another proposal to require smoke alarms in homes with children present, which would have cost only $\$ 200,000$ per life saved, was rejected. The authors found that the best estimate of total life-years saved from all of the adopted regulations was 592,000 per year at a cost of approximately $\$ 21.4$ billion. Had this sum been spent in the most effective way, the total annual number of life-years saved would have been 1,230,000, or more than double the number currently being saved.

Another recent study compiled the results of ninety-one benefit-cost analyses undertaken for major regulations adopted or pending in the United States from 1990 to 1995 (Hahn 1996). The good news, according to the study, is that all fifty-four final regulations adopted, taken together, generated net benefits of nearly $\$ 300$ billion in discounted present value. ${ }^{17}$ The bad news is that thirty-one of these regulations have negative net benefits, and three had negative net benefits exceeding $\$ 10$ billion.

The primary controversial issues concerning economic policy analysis are how it should be undertaken and what status it should have in the regulatory process. Proposals about the formal role of economic analysis range from establishing an agency for undertaking such analyses, to

17. The good news is not without qualification, for this finding rests on the accuracy of the assessment of the risks that gave rise to the regulation, but as Hahn (1996) points out, in many cases these risks are substantially overstated by regulatory agencies. 
allowing the agency to select its targets and to have standing in regulatory proceedings, to requiring that all regulations pass a benefit-cost test before they are adopted. OECD member countries illustrate almost the full range of possibilities (OECD 1995b).

A group of U.S. economists has proposed a new role for benefit-cost analysis in environmental, health, and safety regulation (Arrow et al. 1996a, 1996b). They set out the purposes of analysis: to encourage greater consistency and transparency in regulatory policy, as well as to improve the efficiency of regulation. To this end, they propose that all major regulations be subject to mandatory benefit-cost analysis before a final regulation is adopted. In addition, they propose that all benefit-cost analyses have three features: first, the analysis should be based on a common set of assumptions about common parameters, such as the social discount rate and the value of reductions in morbidity and mortality; second, the analysis should examine the sensitivity of the magnitude of net benefits to the values of key parameters of the analysis; and third, the analysis should be subject to a system of peer review. Finally, they propose that agencies be required to justify rejecting a regulation expected to yield positive net benefits and adopting a regulation that has negative net expected benefits or that achieves positive net benefits only when it uses nonstandard assumptions about key parameters. A similar proposal was made by a panel of expert advisers to the Commission of the European Communities.

Making economic policy analysis mandatory is controversial, and indeed the commission rejected the proposal of its expert panel, making reference to standard arguments against mandatory policy analysis:

The Commission supports the thrust of this proposal. But the practicability of cost-benefit analysis has to be examined on a case by case basis. In the particular field of the environment, there is a question of what constitutes a "reasonable" balance between costs and benefits. The benefits for environment and society are mostly qualitative and often impossible to express in monetary values unlike, for example, the costs to business. The Treaty (130r(3)) also requires that the costs and benefits of non-action also be examined. (Commission of the European Communities 1995, 26-27)

The commission's decision to reject the proposal that all regulations must generate positive net benefits is reasonable, but the reasons given contain important misperceptions, and the decision not to require systematic economic policy analysis is not supported by these reasons.

To begin, a competent benefit-cost analysis does not ignore the costs and benefits of inaction. Benefits and costs are measured as incremental changes from the status quo, so that the net benefits of a policy change are identically equal to the net cost of inaction. Indeed, a competent benefit-cost analysis goes beyond this to estimate the incremental benefits 
and costs of all relevant alternatives to both the status quo and the proposed regulation.

Another important misperception is the statement by the commission that costs are easier to quantify than benefits, biasing benefit-cost analysis in favor of inaction. This statement reflects a fundamental error in the commission's reasoning: "Cost" in benefit-cost analysis does not refer to the financial cost to producers in complying with the regulation but instead to the social cost of adopting the regulation. These concepts are not the same for two basic reasons: uncertainties and unquantifiable effects affect the cost side as well as other forms of information that are essential to formulating regulations, and the presence of imprecision is a matter to be identified and explicitly taken into account, not to be ignored by sweeping analysis under the rug.

On the cost side, allocating resources to regulatory compliance, instead of other activities, also poses risks to life and the environment that are difficult to quantify. The issue of evaluating life actually demonstrates the value of careful economic analysis. Disposable family income is strongly correlated with rates of morbidity and mortality. One study estimates that if a regulatory action imposes a cost of $\$ 50$ million, the regulation will cause one additional death due to the reduction in purchasing power that must occur to pay for the cost of the regulation (Viscusi 1996). And if a regulation causes a reallocation of economic activity to other products, this reallocation inevitably leads to increases in exposure to other hazards and environmental damage, in part offsetting the benefits of the regulation. Whereas the appropriate number for the value of a life saved is surely subject to considerable uncertainty, the preceding observations provide an important insight: most likely, no regulation that imposes a cost exceeding $\$ 50$ million per life saved should be adopted, not because $\$ 50$ million is a good estimate of the value of a life, but because a regulation that costs that much will cause at least as much indirect damage as it is intended to cure.

Mandatory economic analysis of regulatory policies is related to international trade because it facilitates identifying whether regulations promote efficiency or distort trade. An agreement among nations to use common analytical methods for evaluating regulatory proposals drives regulation in each nation toward efficient policies and thereby reduces the distortions arising from regulations of different efficiency among nations. In this sense, adopting a common efficiency metric for domestic regulatory actions has the same role in reducing trade distortions as does a common agreement to reduce tariffs in that both reduce the wedge between actual prices and social costs of production. Moreover, agreement about methods for evaluating regulations is a necessary component of a mechanism for resolving trade disputes over the ultimate purposes and effects of regulations. In particular, a competent economic analysis can distinguish 
regulations that have an anticompetitive purpose and distort trade from regulations that are efficient even though they have differential impacts on some imports.

\subsection{International Regulatory Reform and Trade}

Until recently, the regulatory reform debate has been regarded primarily as an issue of domestic economic policy. As implied by the discussion of electronic commerce and of the trade distortions created by differences in regulatory efficiency among nations, a narrow, nationalistic view of regulatory reform is not valid. As a result, recent trade negotiations and agreements inevitably have included provisions relating to regulatory issues. For example, the Uruguay Round led to an agreement that internal political constraints could not override principles of open access and created a WTO Committee on the Environment. ${ }^{18}$

Regulatory distortions take two conceptually distinct forms: domestic and international. This conceptual division implies a scheme for setting priorities: focus international agreements on regulatory issues that cause significant international distortions. The inefficiencies of regulation that are purely domestic are not necessarily an international priority for reform. Whereas these effects are unfortunate, the costs mostly are confined to the country that causes them. If inefficient regulation has significant international repercussions, coordination and cooperation among nations in regulatory reform have the same status as multinational arrangements for reducing direct trade barriers. Mutuality in reform creates economic benefits that are broadly shared among domestic consumers and trading partners.

As a practical matter, very little distorting regulation has purely domestic effects. International boundaries rarely define natural market barriers that cannot be crossed, and in most cases, the most efficient organization of an industry is international. For example, infrastructural industries (energy utilities, communications, transportation, and finance) all operate more efficiently if their networks are organized according to the pattern of transactions, and in a relatively open world economy, these patterns do not respect national borders. But even if markets are national or indeed local, entry by foreign firms can be an important source of price competition and productivity improvements. Many segments of retail trade are more efficient if international chains of outlets and, of course, electronic commerce are permitted. Hence, both market access for foreign-made goods and openness to foreign investment promote economic growth, and regulations that prevent either create distortions of international signifi-

18. For a discussion of the incorporation of environmental issues into trade agreements and enforcement organizations, see Roessler (1996a). 
cance. International agreements about regulation are the natural vehicle to eliminate these distortions.

An additional advantage of internationalizing regulatory reform is that it can be used to elevate the domestic political debate about regulation from narrow issues to matters of national economic performance and international cooperation. From a political perspective, making regulatory reform an international issue is highly desirable. A common political barrier to domestic regulatory reform is that if reform is perceived as a domestic issue and is debated one issue at a time, well-organized special interests are more likely to have the political power to block it. For most specific regulatory issues, the beneficiaries of reform are numerous, but their per capita benefits are often too low or too indirect to generate significant political pressure for reform. If the reform debate is elevated to a matter of international policy that encompasses numerous reform issues, broader attention and participation from all interests is more likely, thereby reducing the ability of a single interest to block reform.

A useful analogy is to the process of setting tariffs (see Goldstein 1996). When each nation independently sets each tariff separately, the resulting tariffs are likely to be higher than those that would have been negotiated bilaterally as part of a comprehensive trade agreement. The reason is that debating tariffs one product at a time maximizes the undue influence of organized interests with a direct stake in the policy. If a tariff on a specific product is under review, the domestic industry that produces the product is likely to be intensely interested and to exercise whatever political influence it has to obtain a policy decision favorable to itself; however, because the final price of the product is less important to individual buyers than to individual producers, the former are less likely to participate in the debate. Consequently, each important trade-sensitive industry may receive and preserve a tariff or a favorable regulation when policy is debated in a purely domestic context one industry at a time, but it may receive neither protective tariffs nor protective regulations when policy is developed multinationally and covers many industries.

When each regulation is considered separately as a matter of domestic policy within a specialized agency, the government is likely to be under less pressure to adopt an efficient policy. If a regulation imposes unnecessary costs uniformly on firms in a domestic industry, sales of the industry's product may be suppressed somewhat by higher prices, but the individual firms are unlikely to suffer much because none is at a disadvantage relative to a competitor. If international trade threatens the industry, however, the industry will energetically seek relief. The politically expedient move may be to inhibit trade competition, either by using regulation as an indirect trade barrier or by banning trade while making a rhetorical attack on the lax standards of a trading partner. This approach placates the regulated industry and other interests that place high value on the regulatory policy. 
The primary organized harmed interest, foreign producers, is more easily ignored because they do not participate in domestic politics.

Just as simultaneous negotiation over tariffs on all products conduces to agreements that provide freer trade, so too does simultaneous negotiation of numerous areas of regulation facilitate the elimination of regulatory indirect trade barriers. As with tariffs, the inclusion of multiple regulatory policies within the same negotiation creates more opportunities for mutually beneficial bargains to reduce distortions simultaneously on all fronts. Recent experience with multilateral negotiations bears out this belief. ${ }^{19}$ On both the trade and regulatory fronts, with the exceptions of the Agreement on Trade in Civil Aircraft and the voluntary agreement to liberalize telecommunications access, no single-issue negotiation under the General Agreement on Tariffs and Trade (GATT) and few outside of it have produced a significant commitment to openness, and many have included new, onerous regulatory requirements. Examples of failures are the International Dairy Agreement, which establishes minimum world prices for dairy products; the Multi-Fiber Arrangement, which countenanced import quotas; and the Montreal Protocols, which set world limits on emissions of ozone-depleting chlorofluorocarbons (CFC) but prohibited reallocation among nations of either production or consumption of CFCrelated products through trade or international investment.

The lesson from these examples is that incorporation of regulation into trade agreements should follow the same principles that have been generally followed with respect to tariffs and quotas. Specifically, if regulatory policy is part of an international agreement, it must reduce, not increase, distortions in the international economy and extend, not contract, the extent of liberalization. Introducing regulation into single-product negotiations tends to increase trade distortions (as regulation is used to inhibit trade). In particular, negotiations about a single product or area of regulation risk creating an alliance between protectionists and the most ardent advocates of a particular regulatory policy who seek regulations that go far beyond those that maximize net social benefits.

The same argument applies to the enforcement of agreements not to adopt anticompetitive regulations. If enforcement powers reside solely in domestic agencies, a case in which a regulation places foreign producers at a disadvantage rests on unbalanced underlying politics. Domestic producers are likely to be more effectively represented than foreigners in the agency and in the background political system within which the agency must operate. Consequently, actions to eliminate the anticompetitive international effects of regulation are likely to face more political resistance than support.

International institutions for resolving regulatory trade disputes operate

19. For more details on the examples presented in this paragraph, see Roessler (1996b). 
in a more balanced political environment. These institutions can be a means through which nations mutually can commit to maintain procompetitive regulatory reforms. The GATT and WTO disputes about automobile fuel efficiency and reformulated gasoline illustrate how domestic regulatory agencies but not international institutions are willing to sacrifice competition as well as some of the effectiveness of regulatory policies in order to favor domestic producers.

For these reasons, internationalization of regulatory reform can succeed by enfranchising foreign producers in domestic regulatory policy across a spectrum of industries. In the context of a dispute about the trade effects of a particular regulation, intervention by an international organization often is met with cries of outrage - an intervention by foreigners into domestic policy. All international agreements entail some loss of the ability to act independently in order to achieve something else of value, which in this case is a worldwide regulatory system that is more efficient and freer of trade distortions. Such an institution generates net economic benefits to each country, even if some cases create some domestic losers. The creation of institutions for enforcing agreements to eliminate indirect trade barriers is a means to balance the political influence of these domestic losers.

The growing movement for regulatory reform throughout the world has increased the potential significance of internationalizing the reform process. If some nations operate a relatively efficient regulatory system while others do not, international cost differences arising from regulation are likely to surface as political issues in high-cost countries. Perhaps the result will be reform, but another plausible scenario is protection against "unfair" competition. Initiating multisectoral international negotiations over phased reform offers an opportunity to seize the initiative, casting the agenda in terms of improved efficiency rather than retaliation against unfair trade. Domestic reform that enfranchises competition policy agencies facilitates free trade by promoting reforms of regulatory policies that erect entry barriers. Reforms that impose mandatory benefit-cost analysis facilitate free trade by creating a stronger information base from which to challenge regulatory trade barriers in international dispute resolution institutions. Finally, designing these same dispute resolution entities to incorporate the principles of competition policy and economic policy analysis has two potential benefits: regulations are identified that have no plausible rationale other than to place foreign competition at a disadvantage, and beyond this, the degree to which differences in regulatory policy create differential regulatory efficiency is reduced. Both effects of the internationalization of regulatory reform serve the objectives of international openness and help to eliminate an important source of distortions in the international economy. 


\section{References}

Anderson, Mikael Skou. 1994. Economic instruments and clean water: Why institutions and policy design matter. PUMA/REG(94)5. Paris: Organization for Economic Cooperation and Development, April.

Armstrong, Mark, Simon Cowan, and John Vickers. 1994. Regulatory reform: Economic analysis and British experience. Cambridge, Mass.: MIT Press.

Arrow, Kenneth J., Maureen L. Cropper, George C. Eads, Robert W. Hahn, Lester B. Lave, Roger G. Noll, Paul R. Portney, Milton Russell, Richard Schmalensee, V. Kerry Smith, and Robert N. Stavins. 1996a. Benefit-cost analysis in environmental, health and safety regulation: $A$ statement of principles. Washington, D.C.: American Enterprise Institute.

1996b. Is there a role for benefit-cost analysis in environmental, health, and safety regulation? Science 272:221-22.

Baily, Martin Neal. 1993. Competition, regulation, and efficiency in service industries. Brookings Papers on Economic Activity: Microeconomics, no. 2:71-130.

Baron, David. 1989. The design of regulatory mechanisms and institutions. In The handbook of industrial organization, ed. Richard Schmalensee and Robert Willig. New York: North-Holland.

Bernstein, Jeffrey I. 1988. Dynamic factor demands and adjustment costs: An analysis of Bell Canada's technology. Information Economics and Policy 3:5-24.

Breyer, Stephen. 1982. Regulation and its reform. Cambridge, Mass.: Harvard University Press.

Button, Kenneth, and Thomas Weyman-Jones. 1994a. Impacts of privatization policy in Europe. Contemporary Economic Policy 12, no. 1 (October): 23-33.

-. 1994b. X-efficiency and technical efficiency. Public Choice 80 (1): 83-103.

Commission of the European Communities. 1995. Comments of the Commission on the report of the Independent Experts Group on Legislative and Administrative Simplification. SEC(95) 2121 final. Brussels.

Crandall, Robert W., and Leonard Waverman. 1996. Talk is cheap: The promise of regulatory reform in North American telecommunications. Washington, D.C.: Brookings Institution.

Galal, Ahmed, Leroy Jones, Pankaj Tandon, and Ingo Vogelsang. 1994. Welfare consequences of selling public enterprise: An empirical analysis. New York: Oxford University Press.

Goldstein, Judith. 1996. International institutions and domestic politics. Stanford, Calif.: Stanford University, Center for Economic Policy Research. Working paper.

Greenstein, Shane, Susan McMaster, and Pablo T. Spiller. 1994. The effect of incentive regulation on local exchange companies' deployment of digital infrastructure. Urbana: University of Illinois, June. Working paper.

Hahn, Robert W. 1989. Economic prescriptions for environmental problems: How the patient followed the doctor's orders. Journal of Economic Perspectives 3, no. 2 (spring): 94-114.

- 1996. Regulatory reform: What do the government's numbers tell us? In Risks, costs, and lives saved: Getting better results from regulation, ed. Robert W. Hahn. New York: Oxford University Press.

Hahn, Robert W., and Roger G. Noll. 1982. Designing a market for tradable emissions permits. In Reform of environmental regulation, ed. Wesley Magat. Lexington, Mass.: Lexington.

Hartman, Raymond S., and David Wheeler. 1995. Incentive regulation: Market- 
based pollution control for the real world. In Regulatory policies and reform: $A$ comparative perspective, ed. Claudio R. Frischtak. Washington, D.C.: World Bank, Private Sector Development Department.

Helm, Dieter. 1998. The assessment of environmental policy B objectives, instruments, institutions. Oxford Review of Economic Policy 14, no. 4 (winter): 1-19.

Joskow, Paul L. 1998. Electricity sectors in transition. Energy Journal 19 (2): 25-52.

Joskow, Paul L., and Roger G. Noll. 1999. The Bell doctrine. Stanford Law Review 51 (5): 1249-1315.

Majumdar, Sumit K. 1995. Regulation and productive efficiency: Evidence from the U.S. telecommunications industry. Ann Arbor: University of Michigan, July. Working paper.

McCubbins, Mathew D., Roger G. Noll, and Barry R. Weingast. 1987. Administrative procedures as instruments of political control. Journal of Law, Economics and Organization 3 (2): 243--77.

_ 1989 . Structure and process, politics and policy: Administrative arrangements and the political control of agencies. Virginia Law Review 75, no. 2 (March): 431-82.

Nelson, Randy A., and Walter J. Primeaux. 1988. The effects of competition on transmission and distribution costs in the municipal electric industry. Land Economics 64 (November): 338-46.

Noll, Roger G. 1995. The role of antitrust in telecommunications. Antitrust Bulletin, fall: $501-28$.

1997. Internationalizing regulatory reform. In Comparative disadvantage, ed. Pietro S. Nivola, 319-55. Washington, D.C.: Brookings Institution.

- Forthcoming. Telecommunications in developing countries. In Economic policy reform: The second stage, ed. Anne O. Krueger. Chicago: University of Chicago Press.

Noll, Roger G., and Bruce M. Owen. 1994. The anticompetitive uses of regulation: United States v. AT\&T (1982). In The antitrust revolution, 2d ed., ed. John E. Kwoka Jr. and Lawrence J. White, 328-75. New York: Harper Collins.

Noll, Roger G., and Frances M. Rosenbluth. 1995. Telecommunications policy: Structure, process, outcomes. In Structure and policy in Japan and the United States, ed. Peter F. Cowhey and Mathew D. McCubbins, 119-76. New York: Cambridge University Press.

Noll, Roger G., Mary M. Shirley, and Simon Cowan. Forthcoming. Reforming urban water systems in developing countries. In Economic policy reform: The second stage, ed. Anne O. Krueger. Chicago: University of Chicago Press.

O'Connor, D. 1991. Policy and entrepreneurial response to the Montreal Protocol: Some evidence from the dynamic Asian economies. Technical Paper no. 51. Paris: Organization for Economic Cooperation and Development, Development Center.

1993. Managing the environment with rapid industrialization. Paris: Organization for Economic Cooperation and Development, Development Center. OECD (Organization for Economic Cooperation and Development). 1992. Structure and change in distribution systems: An analysis of seven OECD member countries. ECO/CPE/WP1(92)7. Paris: Organization for Economic Cooperation and Development, Economics Department.

- 1994a. Mini-roundtable on the role and enforcement of competition policy in regulated sectors. DAFFE/CLP/M(94)2/ANN4. Paris: Organization for Economic Cooperation and Development, Directorate for Financial, Fiscal and Enterprise Affairs.

1994b. Role and enforcement of competition policy in regulated sectors: 
Note by the Netherlands delegation. DAFFE/CLP(94)14. Paris: Organization for Economic Cooperation and Development, Directorate for Financial, Fiscal and Enterprise Affairs.

1995a. Competition policy and the agro-food sector. COM/AGR/APM/

TD/WP(95) 73/REV1. Paris: Organization for Economic Cooperation and Development, Directorate for Food, Agriculture and Fisheries.

-1995b. Control and management of government regulation. PUMA(95)9.

Paris: Organization for Economic Cooperation and Development, Public Management Service.

-. 1995c. Parcel delivery in the global marketplace. Paris: Organization for Economic Cooperation and Development, Committee on Consumer Policy.

- 1996a. Consumer product safety standards and conformity assessment:

Their effect on international trade (draft). Paris: Organization for Economic Cooperation and Development, Committee on Consumer Policy.

1996b. Information infrastructure convergence and pricing: The Internet.

Paris: Organization for Economic Cooperation and Development, Working Party on Telecommunications and Information Services.

1996c. Regulatory reform: A country study of Australia. PUMA REG(96)1. Paris: Organization for Economic Cooperation and Development, Public Management Service.

Pollitt, Michael G. 1993. The relative performance of publicly owned and privately owned electric utilities. Ph.D. diss., Oxford University, Oxford.

Roessler, Frieder. 1996a. Diverging domestic policies and multilateral trade integration. In Fair trade and harmonization: Prerequisites for free trade? vol. 2, Legal analysis, ed. Jagdish Baghwati and Robert Hudec, 21-55. Cambridge, Mass.: MIT Press.

1996b. Efficient and inefficient issue linkages in multilateral negotiations: A critical examination of the "trade and ..." trend. Stanford, Calif.: Stanford University, Center for Economic Policy Research. Working paper.

Shabecoff, Philip. 1996. A new name for peace: International environmentalism, sustainable development, and democracy. Hanover, N.H.: University Press of New England.

Tengs, Tammy O., and John D. Graham. 1996. The opportunity costs of haphazard social investments in life-saving. In Risks, costs, and lives saved: Getting better results from regulation, ed. Robert W. Hahn. New York: Oxford University Press.

Utility Data Institute. 1992. State directory of new electric power plants. Washington, D.C.: Utility Data Institute.

Vickers, John, and George Yarrow. 1988. Privatization: An economic analysis. Cambridge, Mass.: MIT Press.

Viscusi, W. Kip. 1996. The dangers of unbounded commitments to regulate risk. In Risks, costs, and lives saved: Getting better results from regulation, ed. Robert W. Hahn. New York: Oxford University Press.

Vogel, David. 1997. Trouble for us and trouble for them: Social regulations as trade barriers. In Comparative disadvantage, ed. Pietro S. Nivola, 98-128. Washington, D.C.: Brookings Institution.

Wilcynski, P. 1990. Environmental management in centrally planned non-market economies of Eastern Europe. Working Paper no. 35. Washington, D.C.: World Bank, Environment Department.

Winston, Clifford. 1993. Economic deregulation: Days of reckoning for microeconomists. Journal of Economic Literature 31, no. 3 (September): 1263-89.

World Bank. 1995. Bureaucrats in business. New York: Oxford University Press. 


\section{Comment Anne O. Krueger}

This is a very rich paper, from which I learned a lot. The impression that stands out, among many others, is the great extent to which regulation and trade policy issues overlap and yet have been analyzed by two separate communities, with much less cross-fertilization than would have been desirable. Coming from the perspective of trade policy, I hope that Roger Noll's paper will make a major breach in the wall separating the two areas, and I believe that trade policy analysts will greatly benefit from this, and hopefully further, interaction.

Noll starts by noting the distinction between efficient regulationwhich occurs when market failures are compensated for in a least cost way by public policy that results in an increase in social welfare-and actual regulation, which may have much higher cost because of nonoptimal regulatory behavior or because costs exceed the social benefits of regulation. Distinguishing between instances of market failures that policy can beneficially correct and instances where regulation is either inefficient or favors the regulated is a primary concern of policy analysis in the regulatory arena. In the past two decades, much regulation has been overhauled as inefficiencies have come to be recognized.

For international trade policy, the appropriate analogue would appear to be distinguishing between instances in which there are legitimate bases for protection (national defense, perhaps) and cases in which pleas for protection are based on legitimate issues (or on issues that garner political support) but come from those producers who expect to benefit privately. No producer has ever based his case for protection solely on the proposition that he alone will be better off with protection: the argument is always couched in terms of the social benefits of the industry, the unfair competition from abroad, the threat to jobs, or other aspects of the social good. A major difficulty with calls for linkages between trade and the environment has been that many of those most enthusiastically endorsing the linkage are those who would most benefit from protection.

But as Noll points out, as artificial trade barriers-primarily tariffs-have fallen, the possibility of international distortions arising out of inefficient regulation, or the interaction of inefficient regulation and protection, has made it all the more urgent to achieve efficient regulation, and in his view to achieve international agreements on regulatory regimes as well. That firms in one country are more sensitive to (artificial or economic) small cost differences because of lowered trade barriers and transport costs goes without saying.

Anne O. Krueger is the Herald L. and Caroline L. Ritch Professor of Economics, senior fellow of the Hoover Institution, and director of the Center for Research on Economic Development and Policy Reform at Stanford University, and a research associate of the National Bureau of Economic Research. 
The question is the extent to which international agreements can be reached that genuinely reduce the artificial cost differences resulting from differences in national regulatory regimes (so, e.g., that there is a race to the bottom), as contrasted with the extent to which some countries will be enabled to impose their preferences on other countries in response to protectionist pressures from domestic producers. Especially for poor countries, the risk that the OECD countries may try to impose their environmental preferences (even when there are no international spillovers) on poorer countries is real. While Noll recognizes that such an outcome is possible, he is more sanguine than I am that an efficient outcome can be achieved.

It is certainly true that pressures for an international "competition" policy, or common rules of the game for producers in different countries, are growing. And the absence of common rules is used as an excuse for seeking protection. However, while market failure can justify regulation, government failure also has risks. As anyone dealing with trade policy issues is well aware, lobbyists seem to have even more disproportionate influence on trade policy than they do on matters of domestic interest.

The real challenge is to find ways to achieve international agreement on a competition (or regulatory) policy that is socially efficient and does not provide cover for protectionist measures. Anyone recognizing how difficult it has been to reach agreement even on such matters as customs procedures, scientific criteria for phytosanitary standards, and mutual recognition of standards among developed countries will naturally be less than sanguine about the prospects, at least in the next several years, for achieving an efficient international competition policy. Government failure has been more prominent than market failure in international trade.

Nonetheless, I think I agree with the conclusion: as other trade barriers and transactions costs fall, it will be increasingly important to achieve a satisfactory competition policy as protectionist pressures mount. Searching for ways to ensure that such an agreement is socially efficient is surely an endeavor where the benefit-cost ratio can be very high.

\section{Comment Sadao Nagaoka}

This is a highly informative paper and poses a number of challenging questions for future regulatory reform. Although I support many of its conclusions, I have two reservations with regard to its international aspects.

Sadao Nagaoka is professor of management and economics at the Institute of Innovation Research of Hitotsubashi University. 


\section{International Impact of Domestic Regulation}

Inefficient domestic regulation distorts resource allocation but does not necessarily harm trading partners. It does so when such regulation reduces trading or investment opportunities or when it has a negative cross-border spillover, such as acid rain. Otherwise, inefficient regulation harms only the home country. Noll, however, seems to assume that inefficient regulation pervasively reduces the welfare of trading partners. For example, he argues that a country with strict environmental regulation will lose "efficient" industry if it liberalizes trade with a country with lax environmental regulation. But from the national welfare point of view, what determines the efficient use of resources is the difference between domestic production cost and international market price. Thus free trade still benefits the country with high environmental standards.

\section{Necessity of Internationalizing Regulatory Reform}

The necessity of internationalizing regulatory reform seems to be clear when regulation limits market entry, and thus trade and investment opportunities, or when it has direct cross-border spillovers. In this case each country has a clear stake in the progress of the regulatory reform of trading partners. On the other hand, the necessity of internationalizing environmental policy and other regulations generally, as Noll seems to suggest, is not clear at all, since one country's choice of such policies does not materially harm the welfare of other countries, and efficient regulation differs between nations, depending on national conditions. If the internationalization of regulation is pursued in order to level the playing field, there is a clear danger that it will lead to inefficient regulation. 